

\section{NOTICE}

The submitted manuscript has been offered by an employee of the Alliance for Sustainable Energy, LLC (ASE), a contractor of the US Government under Contract No. DE-AC36-08-GO28308. Accordingly, the US Government and ASE retain a nonexclusive royalty-free license to publish or reproduce the published form of this contribution, or allow others to do so, for US Government purposes.

This report was prepared as an account of work sponsored by an agency of the United States government. Neither the United States government nor any agency thereof, nor any of their employees, makes any warranty, express or implied, or assumes any legal liability or responsibility for the accuracy, completeness, or usefulness of any information, apparatus, product, or process disclosed, or represents that its use would not infringe privately owned rights. Reference herein to any specific commercial product, process, or service by trade name, trademark, manufacturer, or otherwise does not necessarily constitute or imply its endorsement, recommendation, or favoring by the United States government or any agency thereof. The views and opinions of authors expressed herein do not necessarily state or reflect those of the United States government or any agency thereof.

Available electronically at http://www.osti.gov/bridge

Available for a processing fee to U.S. Department of Energy and its contractors, in paper, from:

U.S. Department of Energy

Office of Scientific and Technical Information

P.O. Box 62

Oak Ridge, TN 37831-0062

phone: 865.576.8401

fax: 865.576 .5728

email: mailto:reports@adonis.osti.gov

Available for sale to the public, in paper, from:

U.S. Department of Commerce

National Technical Information Service

5285 Port Royal Road

Springfield, VA 22161

phone: 800.553.6847

fax: 703.605.6900

email: orders@ntis.fedworld.gov

online ordering: http://www.ntis.gov/ordering.htm 


\title{
Required Material Properties for High-Efficiency CIGS Modules
}

\author{
Ingrid Repins, Stephen Glynn, Joel Duenow, Timothy J. Coutts, Wyatt K. Metzger, and \\ Miguel A. Contreras \\ National Renewable Energy Laboratory
}

\begin{abstract}
Relatively high proven efficiencies of CIGS devices are often cited regarding its choice as a semiconductor for photovoltaic manufacturing. Module efficiency is an important parameter, as a number of factors in the cost per watt are driven downward by increasing efficiency. Some of these factors include materials costs, throughput for a given capital investment, and installation costs. Thus, realizing high-efficiency (e.g. 15\%) large-area CIGS modules is key in both reducing cost per watt and differentiating the technology from other thin films. This paper discusses the material properties required of each layer of the CIGS device such that large-area CIGS modules can achieve efficiencies $15 \%$, which is substantially higher than the current industrial state-of-the-art. The sensitivity of module performance to the important material parameters is quantified based on both experimental data and modeling. Necessary performance differences between small-area devices and large-area modules imposed by geometry are also quantified. Potential technical breakthroughs that may relax the requirements for each layer are discussed.
\end{abstract}

Keywords: CIGS, module, material properties, photovoltaics

\section{Overview of material properties}

At NREL, small area CIGS device efficiencies of $20.0 \%$ have been demonstrated, ${ }^{1}$ as shown in Figure 1 . Table 1 shows measured material properties for each electrically active layer of an NREL $20 \%$ efficient device. These values will be referred to in the discussion as "best proven" values. In the following sections, each layer of the device is discussed, starting from the light-incident side. For each layer, the sensitivities of the performance to deviations from the best proven values of material properties are discussed. For critical properties, a range of acceptable values for $15 \%$ module performance is established.

\section{Grids and transparent conductor}

Grids and the transparent conducting oxide (TCO) must be considered together, as both are involved in lateral current collection and optimized properties are therefore interdependent. Power losses for the grid and TCO are calculated following Green. ${ }^{2}$

These power losses for an NREL 20.0\% device are calculated and listed in the second column of Table 2. Power absorbed in the TCO, $\mathrm{P}_{\mathrm{TCO}}$, is based on measured TCO absorption (Figure 2), and is calculated by

$$
P_{T C O}=V_{m p} \int A(\lambda) I_{A M 1.5}(\lambda) Q E(\lambda) d \lambda
$$

where $\mathrm{V}_{\mathrm{mp}}=$ maximum power voltage

$$
\begin{aligned}
& \mathrm{A}(\lambda)=\text { fractional absorption as a function of wavelength } \\
& \mathrm{I}(\lambda)=\text { AM1.5 photon current per wavelength } \\
& \mathrm{QE}(\lambda)=20 \% \text { device quantum efficiency }
\end{aligned}
$$

The absorbed photon current listed in Table 1 as "ZnO bi-layer AM1.5 absorption" is simply $\mathrm{P}_{\mathrm{TCO}} / \mathrm{V}_{\mathrm{mp}}$. 
NREL

\section{$\mathrm{CdS} / \mathrm{Cu}(\mathrm{In}, \mathrm{Ga}) \mathrm{Se}_{2}$ Cell}

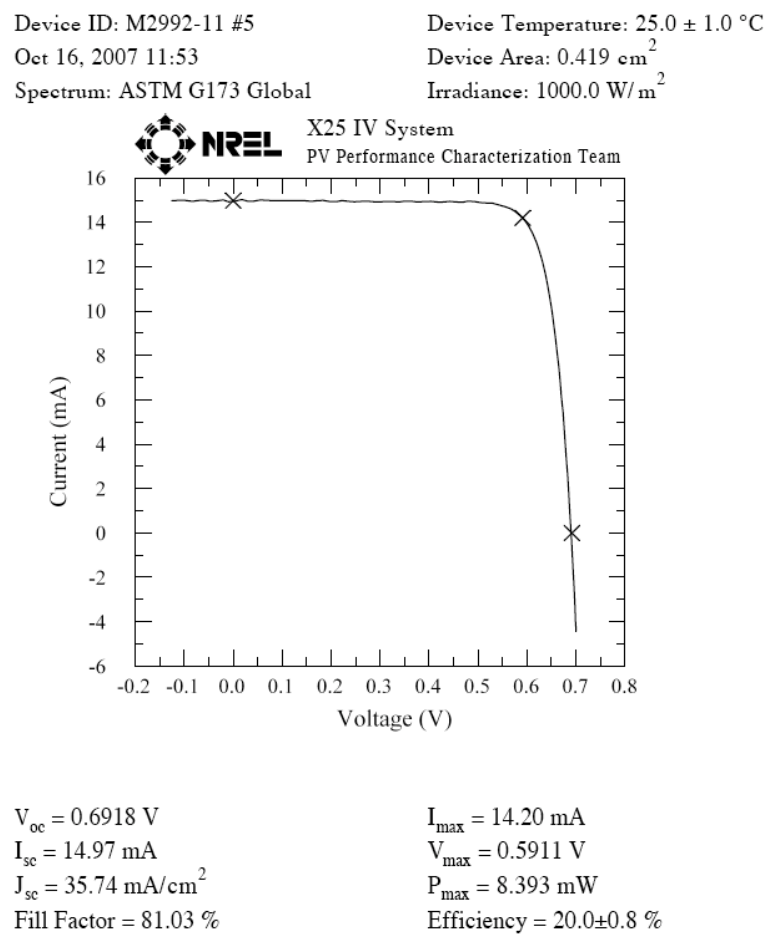

Figure 1: JV curve of $20.0 \%$ CIGS device, using the recently-adopted standard ASTM G173 global spectrum. Note that the same device measures $19.9 \%$, as published, under the earlier standard spectrum.

Table 1: Relevant material properties of NREL $20 \%$ device.

\begin{tabular}{|l|l|l|l|l|}
\hline Layer & Property & Value & Units & Measurement Technique \\
\hline Mo & Sheet Resistance & $<0.24$ & $\Omega / \square$ & Four-point probe \\
\hline CIGS & Thickness & 2.2 & $\mu \mathrm{m}$ & Mechanical profilometer \\
\hline CIGS & Ga ratio & $0.28 / 0.20 / 0.40$ notch & unitless & Auger profiling \\
\hline CIGS & Lifetime & $\sim 200$ & $\mathrm{~ns}$ & Time-resolved photoluminescence \\
\hline CIGS & Carrier density & $2 \times 10^{16}$ & $\mathrm{~cm}^{-3}$ & Capacitance-voltage \\
\hline CdS & Thickness & 50 & $\mathrm{~nm}$ & Mechanical profilometer \\
\hline ZnO bi-layer & Sheet Resistance & 69 & $\Omega / \square$ & Four-point probe \\
\hline ZnO bi-layer & AM1.5 Absorption & 1.0 & $\mathrm{~mA} / \mathrm{cm}^{2}$ & Transmission spectrophotometry \\
\hline ZnO: Al & Carrier density & $5.6 \times 10^{20}$ & $\mathrm{~cm}^{-3}$ & Hall Effect \\
\hline ZnO: Al & Mobility & 13 & $\mathrm{~cm}^{2} / \mathrm{V}-\mathrm{sec}$ & Hall Effect \\
\hline ZnO: Al & Thickness & 120 & $\mathrm{~nm}$ & Mechanical profilometer \\
\hline Grid finger & Sheet resistance & 0.009 & $\Omega / \square$ & Resistance test structure \\
\hline Grid finger & Contact resistance & $4.5 \times 10^{-7}$ & $\Omega-\mathrm{m}^{2}$ & Resistance test structure \\
\hline Grid finger & Minimum width & 45 & $\mu \mathrm{m}$ & Mechanical profilometer \\
\hline
\end{tabular}


Reflection losses are calculated in an analogous fashion, with $\mathrm{A}(\lambda)$ in (1) replaced by the reflection, $\mathrm{R}(\lambda)$. Based on the reflection data of Figure 2, these losses integrate to $4.1 \mathrm{~mA} / \mathrm{cm}^{2}$. However, use of a $\mathrm{MgF}_{2}$ anti-reflective (AR) coating increases the short-circuit current by $5 \%$ (i.e. by $\sim 1.8 \mathrm{~mA} / \mathrm{cm}^{2}$ ), implying reflection losses are reduced to $2.3 \mathrm{~mA} / \mathrm{cm}^{2}$. Thus, the remaining power loss due to reflection in a high-efficiency device (coated with $\mathrm{MgF}_{2}$ ) is approximately 1.4 $\mathrm{mW} / \mathrm{cm}^{2}$.

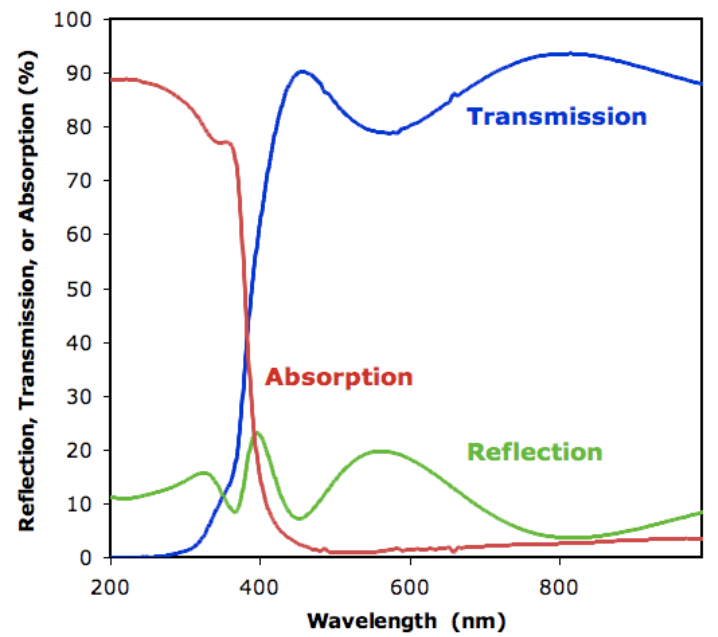

Figure 2: Measured transmission, reflection, and absorption as a function of wavelength for $\mathrm{ZnO}$ bilayer on glass companion piece to device M2992 of Figure 1.

When moving to a larger device size, power loss related to lateral current collection necessarily increases. However, these power losses are minimized by adjusting grid spacing, cell dimensions, and TCO conductivity and absorption (via TCO free carrier density). The necessary performance differences imposed by device size should be distinguished from processing choices made for throughput and cost advantages. For example, a manufacturer may utilize a substrate or deposition rate that has a known negative impact on absorber lifetime, but is advantageous in terms of throughput. In this paper, we only discuss material properties needed to achieve a given performance goal, independent of manufacturing trade-offs.

The geometry utilized to examine power losses for a large-area device is shown in Figure 3. A gridded, rather than monolithically-integrated, configuration is analyzed, as grids have been shown both experimentally and by simulation to maximize efficiency. ${ }^{3}$ The cell length, A, is fixed at $10 \mathrm{~cm}$, taken to be the smallest size reasonable for integration into a large-area module. The bus bar width, $\mathrm{d}$, is fixed at $1.5 \mathrm{~mm}$, a minimum reasonable size for automated stringing. The maximum bus bar sheet resistance is taken to be $0.14 \mathrm{~m} \Omega / \square$, consistent with $13 \mu \mathrm{m}(0.5 \mathrm{mil}) \mathrm{Cu}$ ribbon. $\mathrm{B}$, one half the cell width, and $\mathrm{S}$, the distance between grid fingers, are optimized to minimize power losses. 


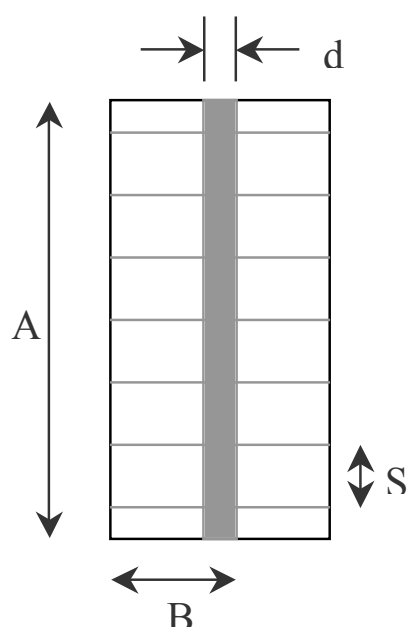

Figure 3: Cell geometry used for analysis of large-area device.

The TCO properties, not just the cell dimensions, must also be optimized for the larger geometry to achieve the highest efficiency. It is assumed for this optimization that the mobility of the TCO is approximately fixed, since the mobility is a function of scattering mechanisms that may not be mutable for a given process or material. The free carrier density, however, is easily varied via oxygen vacancies or dopants in the target. For example, in ZnO films at NREL, changing the Al-doping from 0 to $2 \%$ by weight caused a $20 \mathrm{x}$ increase in carrier density, but only a $2 \mathrm{x}$ decrease in mobility. ${ }^{4}$

Effects of changing the free carrier density on power loss in the device can be calculated using classical harmonic oscillator theory, ${ }^{5,6}$ dictating that the absorption in the TCO is related to conduction following

$$
\begin{gathered}
\alpha=\frac{q^{3}(377 \text { ohms })}{\omega^{2} m^{2} \sqrt{\varepsilon_{\infty}}} \frac{n}{\mu} \\
\sigma=q \mu n
\end{gathered}
$$

$$
A=1-e^{-\alpha t}
$$

where $\quad \alpha=$ absorption coefficient

$\sigma=$ conductivity

$\mathrm{A}=$ absorption

$\mathrm{q}=$ electron charge

$\mu=$ mobility

$\mathrm{n}=$ carrier concentration

$\omega=$ angular frequency of light

$\mathrm{m}=$ carrier mass

$\varepsilon_{\infty}=$ high frequency dielectric constant

$\mathrm{t}=$ film thickness

This theory predicts a linear relationship between $\ln (1-\mathrm{A})$ and $\mathrm{tn} / \mu$, as is demonstrated in Figure 4 for $\mathrm{ZnO}$ films made at NREL. In Figure 4, absorption is measured at $1.1 \mathrm{eV}$, and $\mathrm{Al}$ doping of the films ranges from 0 to $2 \%$ by weight. The 
comparison between experiment and theory should be considered approximate, as no attempt to account for reflection from the back surface of the film ( $\mathrm{ZnO} /$ glass interface) has been made.

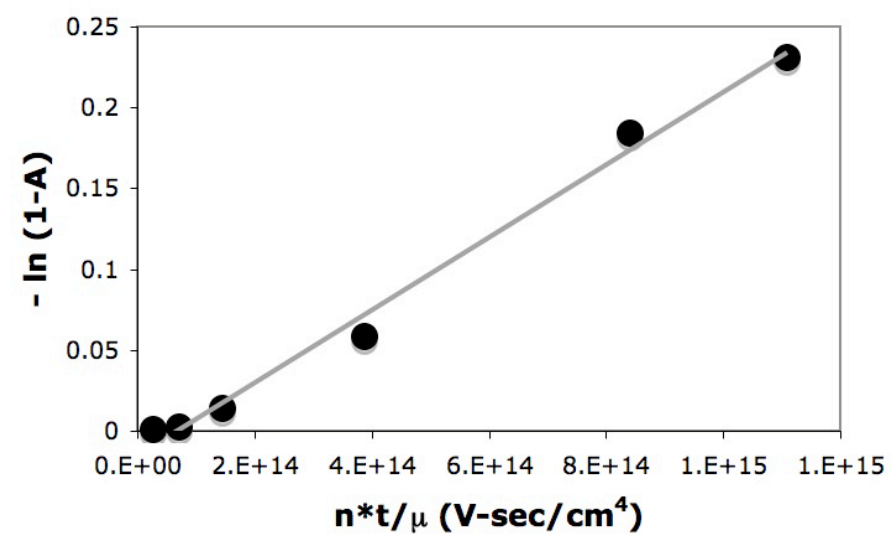

Figure 4: Absorption at $1.1 \mathrm{eV}$ as a function of carrier density, thickness, and mobility measured on NREL ZnO films. The gray line is a linear regression to the data.

Thus, using the material properties of Table 1, the values for B, S, and nt product were adjusted to minimize power loss in the hypothetical large-area device of Figure 3. This minimization was accomplished numerically using a spreadsheet. Resulting parameters are $\mathrm{B}=2.0 \mathrm{~cm}, \mathrm{~S}=1.1 \mathrm{~mm}$, and $\mathrm{nt}=2.3 \times 10^{15} \mathrm{~cm}^{-2}$. Calculated power losses for this configuration are shown in column 3 of Table 2. Power losses not related to the grids and TCO are assumed to be identical to the $20 \%$ small cell. Using the best proven material properties, the highest possible large-area efficiency is thus $19.1 \%$. Alternatively, if the cell width is fixed at $10 \mathrm{~cm}$ (i.e. $\mathrm{B}=5 \mathrm{~cm}$ ), optimized values are $\mathrm{S}=0.61 \mathrm{~mm}$ and $\mathrm{nt}=1.3 \times 10^{15} \mathrm{~cm}^{-2}$, with a resulting efficiency of $18.1 \%$. The power losses for this configuration are listed in column 4 of Table 2 . The 1 to $2 \%$ absolute efficiency difference between the small cell and large cell is consistent with published data and modeling. ${ }^{3}$

The 18 to $19 \%$ efficient large-area prediction is based upon a minimum finger width of grids deposited by e-beam evaporation. Other deposition techniques may necessitate substantially thicker grids. The maximum achievable largearea efficiency is strongly dependent on minimum grid finger width. As grid fingers are made thicker, they must be spaced further apart, resistive loss in the TCO increases, and the optimized TCO is less transmissive. This effect is illustrated in Figure 5, where optimized efficiency and grid spacing are calculated for a $10 \mathrm{~cm}$ wide device. To achieve a module efficiency of $15 \%$, the maximum grid finger width is about $1 \mathrm{~mm}$.

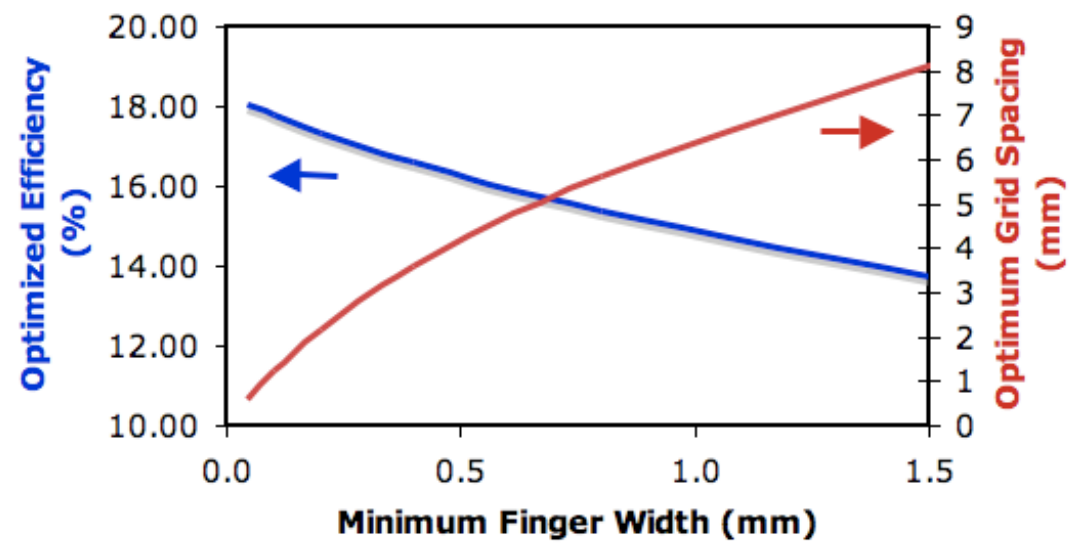

Figure 5: Calculated maximum large-area efficiency as a function of grid finger width. Also shown are the effects of grid finger width on optimum grid spacing. 
Table 2: Optical and resistive losses in optimized devices of varying areas, calculated assuming best proven material properties.

\begin{tabular}{|c|c|c|c|}
\hline Mechanism & $\begin{array}{l}\text { NREL } 20 \% \text { small cell } \\
\text { losses }\left(\mathrm{mW} / \mathrm{cm}^{2}\right)\end{array}$ & $\begin{array}{c}\text { Optimized large } \\
\text { area cell }\left(\mathrm{mW} / \mathrm{cm}^{2}\right)\end{array}$ & $\begin{array}{l}\text { Cell width fixed at } \\
10 \mathrm{~cm}\left(\mathrm{~mW} / \mathrm{cm}^{2}\right)\end{array}$ \\
\hline Grid shading & 0.71 & 0.85 & 1.49 \\
\hline Grid lateral resistance & 0.08 & 0.32 & 1.17 \\
\hline Grid contact resistance & 0.14 & 0.12 & 0.07 \\
\hline TCO resistance & 0.24 & 0.21 & 0.12 \\
\hline TCO absorption & 0.25 & 0.21 & 0.12 \\
\hline Bus bar resistance & 0.13 & 0.14 & 0.36 \\
\hline Bus bar shading & 0.13 & 0.75 & 0.30 \\
\hline Reflection & 1.4 & 1.4 & 1.4 \\
\hline Total: & 3.1 & 4.0 & 5.0 \\
\hline Efficiency (\%): & 20.0 & 19.1 & 18.1 \\
\hline
\end{tabular}

\section{CdS}

The function of the bath-deposited CdS layer has been described not just as a heterojunction partner, but also in terms of band alignment, ${ }^{7}$ lattice matching, ${ }^{8}$ surface cleaning, ${ }^{9,10}$ and formation of a buried heterojunction via Cd doping of the CIGS. ${ }^{10,11,12,13,14}$ It is assumed in this analysis that the CdS deposition conditions allow enough time for adequate surface cleaning and any CIGS doping that might occur. Therefore, the remaining CdS property available for optimization is the CdS thickness.

Device performance as a function of CdS deposition time (i.e. thickness) has been examined at NREL. ${ }^{15}$ From this study, Figure 6 shows open-circuit voltage (Voc), fill factor (ff), and current collection below $520 \mathrm{~nm}$ (from integrated quantum efficiency measurements) as a function of deposition time. Open circuit voltage and fill factor first increase with CdS deposition time then saturate. Current below $520 \mathrm{~nm}$, on the other hand, decreases steadily as absorption in the CdS increases.

The decrease in current with increasing CdS thickness is well-described by integrating the AM1.5 spectrum times the $\mathrm{CdS}$ absorption calculated using published optical constants. To perform this calculation of the CdS absorption, a CdS thickness is assigned to each data point from Figure 6 based on the measured quantum efficiency (QE). Assuming that the ratio of the $\mathrm{QE}$ at $520 \mathrm{~nm}\left(\mathrm{QE}_{520}\right)$ to that at $450 \mathrm{~nm}\left(\mathrm{QE}_{450}\right)$ is controlled by the transmission through the CdS, the thickness $t$ of the $\mathrm{CdS}$ is given by

$$
t=\frac{\ln \left(Q E_{450} / Q E_{520}\right)}{\left(\alpha_{520}-\alpha_{450}\right)}
$$

where $\alpha_{450}$ and $\alpha_{520}$ are the absorption coefficients at 450 and $520 \mathrm{~nm}$, respectively, as available in published data. ${ }^{16}$

Using CdS thickness extracted by this method, the data of Figure 6 are used to graph device efficiency as a function of $\mathrm{CdS}$ thickness, and are shown in Figure 7. Points are measured data, while the dashed line shows the expected dependency at higher thicknesses due to absorption in the CdS. To keep losses from the CdS below $0.5 \mathrm{~mW} / \mathrm{cm}^{2}, \mathrm{CdS}$ thickness must be $40 \mathrm{~nm}+40 /-10 \mathrm{~nm}$. The fairly gentle decrease in efficiency with increased CdS thickness shown in Figure 7 accounts only for increased absorption in the CdS. In practice, it can be expected that for the largest thicknesses shown in the graph, fill factor decreases will occur due to reduced electric field in the CIGS and the 
associated energy position of the CdS/CIGS conduction band offset. ${ }^{17}$ The onset of this fill factor reduction is a function of the $\mathrm{CdS}$ and $\mathrm{i}-\mathrm{ZnO}$ thicknesses and carrier densities.

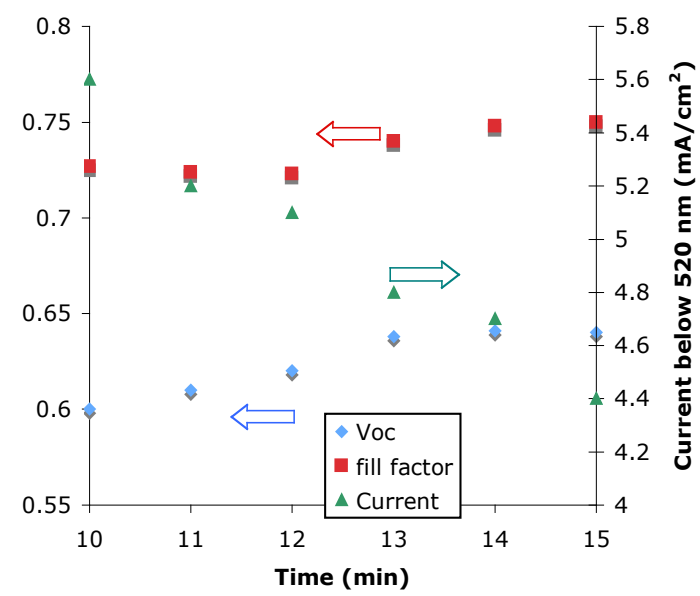

Figure 6: Performance parameters as a function of CdS deposition time (i.e. thickness).

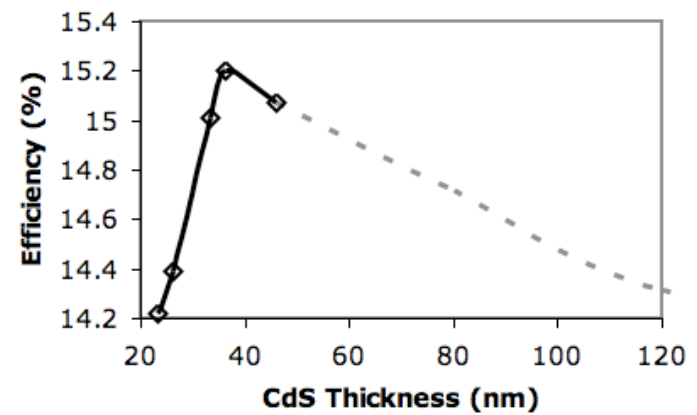

Figure 7: Device efficiency as a function of CdS thickness. Points are measured data, while the dashed line shows the expected dependency at higher thicknesses due to absorption in the CdS.

\section{CIGS}

CIGS, as the absorber and the depleted semiconductor, is the primary layer in determining junction properties and device performance. Its formation tends to be the chief challenge facing manufacturers, as the highest performing CIGS requires the difficult combination of elevated temperatures, extended deposition times, controlled composition and reaction of four elements, Na doping, and large grain size.

Properties of the CIGS that may change from one film to the next and are expected to affect device performance are band gap $\left(\mathrm{E}_{\mathrm{g}}\right)$, lifetime $(\tau)$, carrier density $(\mathrm{p})$, mobility $(\mu)$, and front and rear surface recombination velocities $\left(\mathrm{S}_{\mathrm{F}}\right.$ and $S_{R}$ ). Profiles (gradients) in these properties may occur through the film.

While some of these properties are measured routinely, others are not fully quantified for CIGS. Band gap profile and carrier density profile fall in the more routine category. Band gap profiles are typically deduced from Auger or x-ray photoelectron spectroscopy profiling, and subsequent conversion of the atomic $\mathrm{Ga} /(\mathrm{In}+\mathrm{Ga})$ ratio to band gap. Carrier densities can be deduced from capacitance-voltage or drive-level capacitance profiling, although the separation of free carrier, interface, and deep-level response can be non-trivial. ${ }^{18}$ Lifetime measurements by time-resolved photoluminescence (TRPL) can yield information relevant to device performance, ${ }^{19,20,21}$ although only a single value, 
rather than a profile, is generally extracted. Some (single-value) measurements of hole mobility in CIGS are available in the literature, ${ }^{22,23,24}$ while estimates of the electron mobility are based largely on assumptions regarding the ratio between electron and hole mobilities, or from measurements on single-crystal materials. Little data exists characterizing surface recombination velocities in the CIGS device.

\subsection{BAND GAP PROFILE}

Band gap profile is one of the most thoroughly characterized and understood properties of the CIGS layer. Numerous publications detail how the band gap profile can be manipulated to match the solar spectrum, decouple optical absorption and voltage, and reduce of the effects of back surface recombination and short diffusion length. ${ }^{25}$ In general, the salient features are 1) overall band gap magnitude, 2) single-grading, i.e. increasing the band gap toward the back contact of the device, and 3) double-grading, i.e. creating a "notch" profile that both increases the band gap toward the back and front of the device.

The overall band gap to match the solar spectrum is ideally around $1.4 \mathrm{eV} \cdot{ }^{26}$ In practicality, for CIGS, it is presently limited to about $1.15 \mathrm{eV}$, due to the impact of midgap defects at higher band gaps. The measured band gap profile for the $20.0 \%$ device of Figure 1 is shown in Figure 8. In this data, the atomic ratio $\mathrm{Ga} /(\mathrm{In}+\mathrm{Ga}$ ) was measured by Auger spectroscopy profiling and converted to band gap $\left(\mathrm{E}_{\mathrm{g}}\right)$ using constants provided by Alonso. ${ }^{27}$ The average band gap is around $1.15 \mathrm{eV}$.

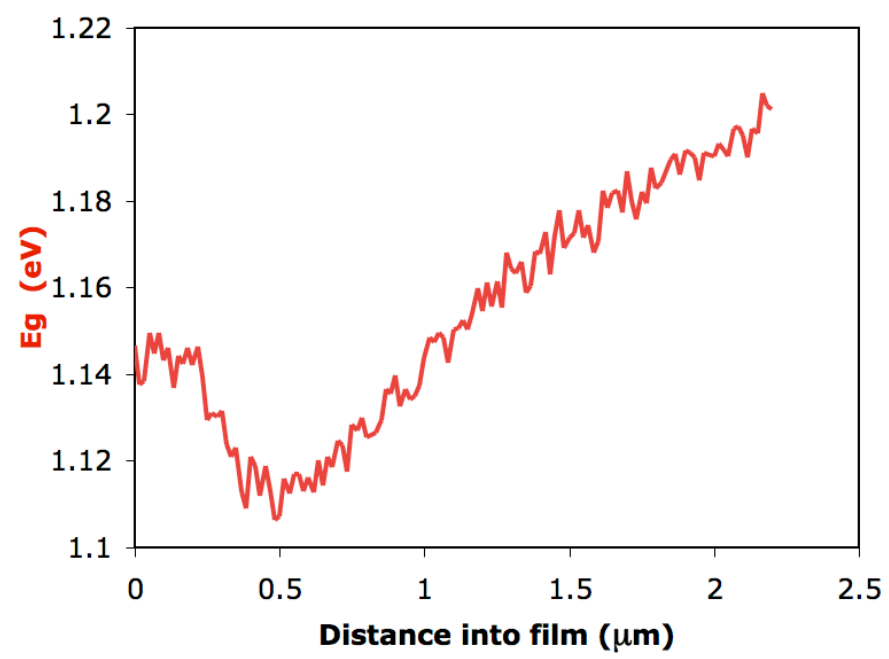

Figure 8: Measured band gap profile of $20.0 \%$ device.

A conspicuous feature of Figure 8 is the "notch" in the band gap profile. The measured profile is similar to the optimum identified by modeling efforts, ${ }^{25,28}$ although the measured band gap minimum is slightly farther from the sample surface and is slightly more shallow than recommended by the models. Based on modeling, the expected benefits of this profile compared to an ungraded absorber are $\sim 0.5 \%$ absolute. ${ }^{25}$ Most of this expected benefit is attributed to the grading toward the back of the device, which reduces back surface recombination and assists in collection. The grading toward the front of the device, which to some extent decouples electrical and optical response, makes a smaller contribution to the improvement.

\subsection{LIFETIME, CARRIER DENSITY, AND MOBILITY}

Lifetime, carrier density, and mobility are logically examined together, as they all occur in a similar fashion in the relationship between forward current and voltage. The forward current density, $\mathrm{J}_{\mathrm{F}}$, in a p-n junction is given by ${ }^{29}$

where $\mathrm{q}=$ electron charge

$$
J_{F}=q \sqrt{\frac{\mu k T}{\tau q}} \frac{n_{i}^{2}}{p} e^{\frac{q V}{k T}}+\frac{q W n_{i}}{2 \tau} e^{\frac{q V}{2 k T}}
$$

$\mathrm{k}=$ Boltzmann constant 


$$
\begin{aligned}
& \mathrm{T}=\text { temperature } \\
& \mu=\text { electron mobility } \\
& \tau=\text { electron lifetime } \\
& \mathrm{n}_{\mathrm{i}}=\text { intrinsic density }=\sqrt{N_{C} N_{V} e^{-E_{g} / k T}} \\
& \mathrm{~N}_{\mathrm{C}}=\text { conduction-band density of states } \\
& \mathrm{N}_{\mathrm{V}}=\text { valence-band density of states } \\
& \mathrm{p}=\text { hole density } \\
& \mathrm{W}=\text { depletion width } \cong \sqrt{2 \varepsilon V_{b i} / q p} \\
& \varepsilon=\text { dielectric constant } \\
& \mathrm{V}_{\mathrm{bi}}=\text { built-in potential }=E_{g}-k T \ln \left(N_{V} / p\right) \\
& \mathrm{V}=\text { voltage applied to the junction }
\end{aligned}
$$

The first term in the right hand side of (6) is forward current due to diffusion $\left(\mathrm{J}_{\mathrm{D}}\right)$, while the second term is forward current due to depletion region recombination $\left(\mathrm{J}_{\mathrm{R}}\right)$. The equation should only be considered a first-order approximation for transport in CIGS devices, as the calculation neglects the effects of finite absorber thickness and assumes uniform absorber properties. Nevertheless, order of magnitude agreement between voltages and lifetimes using this relationship has been demonstrated, ${ }^{21}$ and (6) thus should be a valid vehicle for examining the general trends in expected sensitivity of CIGS device performance to transport parameters.

General trends in the expected impact of $\mu, \tau$, and $\mathrm{p}$ on device performance can be illustrated by examining the forward current near the maximum power point for several parameter values. For such calculations, $\mu, \tau$, and $\mathrm{p}$ were varied, while other material parameters were set to baseline values recommended by Gloeckler, ${ }^{30}$ apart from the electron and hole effective masses $\left(\mathrm{m}_{\mathrm{e}} / \mathrm{m}_{0}\right.$ and $\mathrm{m}_{\mathrm{h}} / \mathrm{m}_{0}$, respectively): CIGS $\mathrm{m}_{\mathrm{e}} / \mathrm{m}_{0}=0.09$, and CIGS $\mathrm{m}_{\mathrm{h}} / \mathrm{m}_{0}=0.72 .{ }^{31}$ The effective masses affect values for band edge densities of states. The lines in Figure 9a show the resulting ratio of the diffusion to recombination current at $\mathrm{V}=$ the maximum power voltage $\mathrm{V}_{\mathrm{mp}}$. For this exercise, $\mathrm{V}_{\mathrm{mp}}$ is taken to be $0.591 \mathrm{mV}$, as in Figure 1. The lines in Figure $9 \mathrm{~b}$ show the total forward current. Calculations are performed for three values of $\mathrm{p}$ and two values of $\mu$, as listed in the figure. The lowest curve (dashed light gray) is calculated using the baseline values for high efficiency devices, $\mathrm{p}=2 \times 10^{16} \mathrm{~cm}^{-3}$ and $\mu=100 \mathrm{~cm}^{2} / \mathrm{V}$-sec. ${ }^{30}$
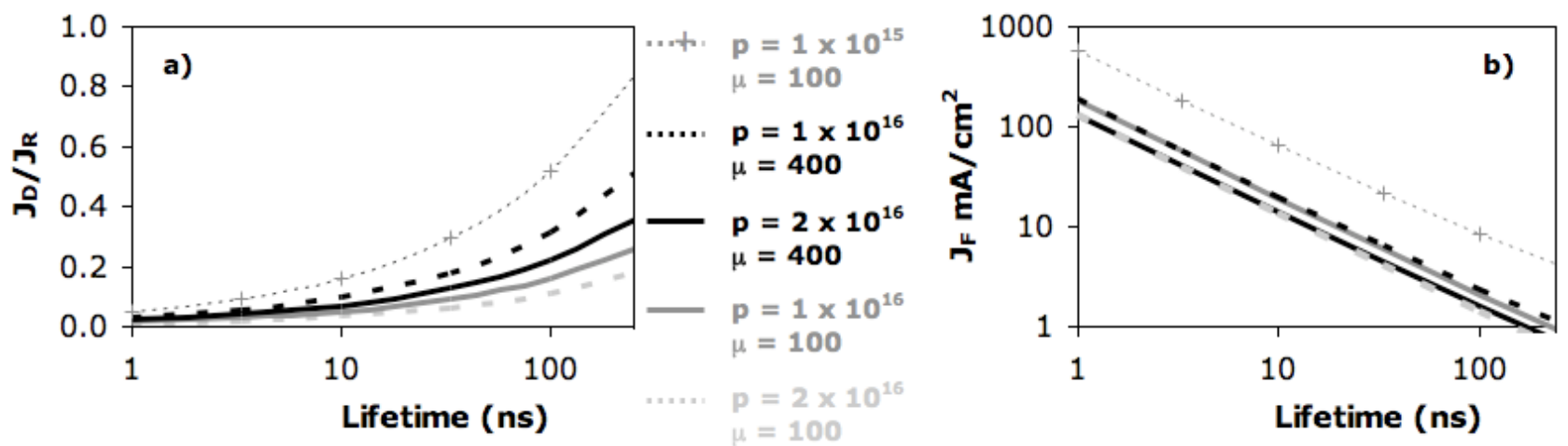

Figure 9: Calculated a) ratio of diffusion current to recombination current, and b) total forward current, as a function of lifetime, for several values of the mobility and carrier density. In the legend, carrier density is listed in $\mathrm{cm}^{-3}$, and mobility as $\mathrm{cm}^{2} / \mathrm{V}$-sec.

For low values of $\tau$, the forward current is dominated by recombination. (i.e. There is a very low value of $J_{D} / J_{R}$ in Figure 9 a). Even above $10 \mathrm{~ns}, \mathrm{~J}_{\mathrm{R}}$ remains the dominant contribution to $J_{F}$, although $J_{D}$ is non-negligible. The critical task of reducing recombination current to increase efficiency is consistent with recent record efficiencies achieved with 
decreasing diode quality factor. ${ }^{1}$ Devices measured at NREL whose material properties are consistent with fabrication of $>15 \%$ modules (i.e. small-area efficiencies $\geq 17 \%$ after application of AR coating) exhibit lifetimes almost exclusively greater than $50 \mathrm{~ns}$. The highest efficiency devices exhibit even longer lifetimes. ${ }^{20}$ It should be noted that meaningful comparison of lifetime across studies requires careful control of measurement conditions as described in the references. ${ }^{19,20}$

In Figure $9 b$, below $\sim 10 \mathrm{~ns}$, the forward current is insensitive to $\mu$, as $\mu$ appears only in the prefactor for $J_{D}$, and $J_{R}$ dominates in this lifetime range. Above $\sim 10 \mathrm{~ns}$, the forward current exhibits some modest dependence on $\mu$ (for constant p), as evidenced by the difference between the solid black and dashed gray lines, or between the dashed black and solid gray lines. Measurements for hole mobilities in CIGS range from 0.1 to $20 \mathrm{~cm}^{2} / \mathrm{V}-\mathrm{sec}^{22,23,24}$ However, little is known about the typical range of electron mobilities in CIGS samples and values required for high performance devices. Because the mobility appears only in the diffusion term of the forward current, it is likely that mobility is of secondary importance compared to lifetime or carrier density. For very high efficiencies, further study of mobility is necessary to comment further on its role in device performance.

For all values of $\tau$, the forward current depends significantly on $\mathrm{p}$, consistent with data in the literature. For small-area devices in the efficiency range of 15 to $18 \%$, a relatively wide range of carrier densities are observed, from around $5 \mathrm{x}$ $10^{15}$ to $2 \times 10^{16} \mathrm{~cm}^{-3} \cdot 21,24,32,33,34,35$ For the devices with efficiencies greater than $19 \%$, however, carrier densities measure over $10^{16} \mathrm{~cm}^{-3}$. Devices with very low carrier density $\left(<10^{15} \mathrm{~cm}^{-3}\right)$ typically exhibit dramatically reduced efficiency $(<10 \%)$.

\subsection{SURFACE RECOMBINATION VELOCITIES}

Although recombination at the back surface is recognized as a mechanism for efficiency loss in the CIGS device, ${ }^{36}$ little data exists characterizing this quantity. Thus, we are unable to comment here on acceptable ranges or typical values for high efficiency devices.

For high-quality CIGS devices, an upper limit of $10^{3} \mathrm{~cm} / \mathrm{s}$ has been deduced for the bare CIGS surface and the CIGS/CdS interface. ${ }^{19}$ Device models predict that a surface recombination velocity of this order of magnitude should have virtually no effect on device performance.

\section{Mo}

Primary functions of the Mo layer are to provide a low-resistance back contact, and - in the case of Na-containing substrates- an adequate Na supply for the growing absorber. How well the latter function is performed depends on the Mo thickness and microstructure, and is evident in the absorber lifetime and carrier concentration.

The conductive requirements for the Mo are fairly easily satisfied, since, unlike the case of the TCO, no transmission is needed. Resistive loss in the Mo is calculated as a function of sheet resistance and cell size by standard methods ${ }^{37}$ and shown in Figure 10. The four lines in Figure 10 correspond to four different geometries for connecting to the back contact of the device in Figure 3. For line A (dashed gray), calculations are performed assuming both long edges are contacted with B set at $2.0 \mathrm{~cm}$, as optimized for the TCO. In this geometry, the largest distance any carrier must travel through the Mo is $2.0 \mathrm{~cm}$. For line A, all values of sheet resistance considered - even those substantially above the demonstrated $0.2 \Omega / \square$ (marked with an arrow) - yield a low power loss. Line B is calculated assuming the same geometry as line A, except only one long edge of the device is contacted. Carriers may travel up to $4 \mathrm{~cm}$ in the Mo. Once again power loss is low. Line $\mathrm{C}$ is calculated assuming the two short edges of the device are contacted, implying a maximum travel distance of $5 \mathrm{~cm}$. Line D is calculated assuming just one short edge of the device is contacted, implying a maximum travel distance of $10 \mathrm{~cm}$. Only for the largest sheet resistances and maximum travel distances shown does power loss in the Mo exceed $1 \mathrm{~mW} / \mathrm{cm}^{2}$.

The requirements on Mo sheet resistance imposed by Figure 10 apply only to devices on insulating substrates. Conducting substrates, e.g. stainless steel foil, are much thicker than the typical Mo coating, and therefore can carry the necessary current without imposing conductivity requirements on the Mo. 

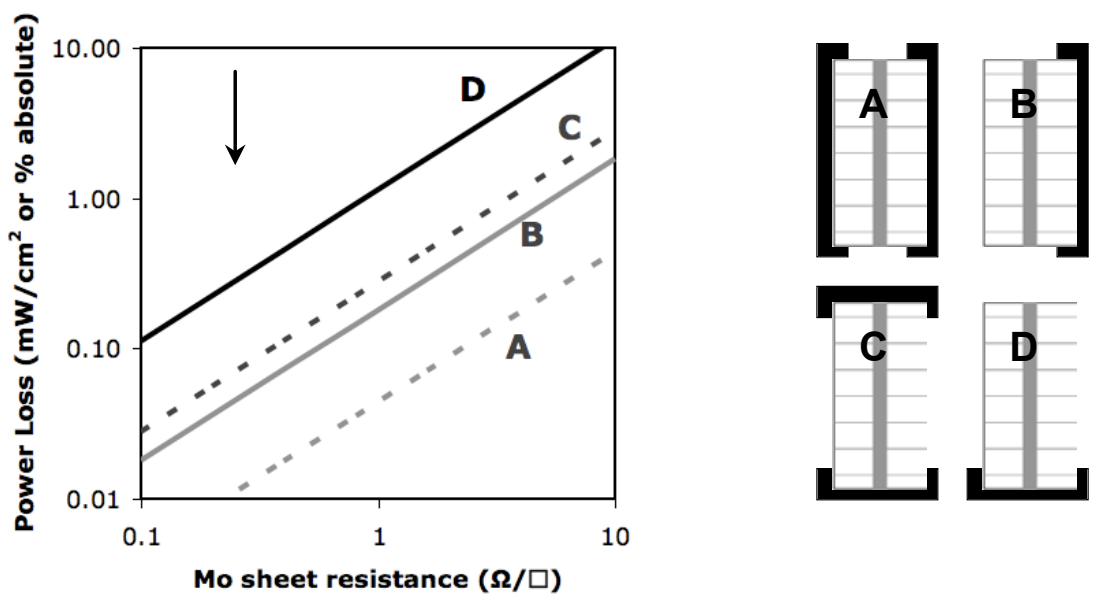

Figure 10: Power loss in the Mo back contact as a function of Mo sheet resistance and geometry. Arrow shows location on graph of demonstrated $0.2 \Omega / \square$ sheet resistance. Schematics on right show geometry used to calculate each line in graph.

\section{Impact of Potential Breakthroughs}

A number of opportunities exist for technological breakthroughs that may relax the material properties requirements delineated in the sections above. These include larger-bandgap absorbers, non-absorbing heterojunction partners that maintain Voc, improved TCOs, and use of optics.

Improved current collection has been the aim of investigation of both larger band gap heterojunction partners and improved TCO's. In the AM1.5 spectrum, $8 \mathrm{~mA} / \mathrm{cm}^{2}$ of photon current is available below $520 \mathrm{~nm}$, and the optimized CdS layer (Figure 7) absorbs $3 \mathrm{~mA} / \mathrm{cm}^{2}$ of it. Thus, a larger band gap heterojunction partner could allow conversion of 3 $\mathrm{mA} / \mathrm{cm}^{2}$ more current, or approximately $1.8 \mathrm{~mW} / \mathrm{cm}^{2}$ more power. Likewise, a perfect TCO (no absorption, resistance, or reflection) would eliminate the grid and resistive layer losses that are shown, for an optimized module, in column 3 of Table 2. These losses total $4 \mathrm{~mW} / \mathrm{cm}^{2}$ to be gained with the development of a perfect TCO.

Larger bandgap absorbers also provide avenues for potential improvement. In theory, larger band gap materials should yield both a better match of the band gap to the solar spectrum, and lower resistive losses. The efficiency gain due to a better match to the solar spectrum, changing the present $\sim 1.15 \mathrm{eV}$ to the optimum $1.4 \mathrm{eV}$ is estimated at $2.5 \%$ absolute. ${ }^{26}$ Reduced resistive losses, on the other hand, can be expected to yield about $0.4 \%$ absolute efficiency increase. This estimate is produced by repeating the TCO/grid optimization of section 2, using a hypothetical $20.0 \%$ efficient wideband gap device with the same outer dimensions as utilized for the optimized large-area device of Table $2(4 \mathrm{~cm} \times 10$ $\mathrm{cm}$ ), with $\mathrm{V}_{\mathrm{mp}}=0.800 \mathrm{~V}$, and $\mathrm{J}_{\mathrm{mp}}=23.6 \mathrm{~mA} / \mathrm{cm}^{2}$. Presently, however, wide band gap chalcopyrites have not yet achieved the absorber and/or interface quality necessary to realize these benefits. ${ }^{38}$

Use of optics produces some efficiency advantages for CIGS solar cells. It should be noted that optics are a slightly different class of improvements than those already discussed, as they require adding components to the device stack, rather than improving or modifying an existing layer. The use of low concentration (14x) has been demonstrated to improve small-area CIGS device efficiency by $3.6 \%$ absolute. ${ }^{39}$ Maintaining low resistances is key in achieving this efficiency increase under concentration. Luminescent frequency conversion has been shown to increase short-circuit current. $^{40,41}$ In this technique, luminescent dyes absorb blue photons that might otherwise be lost in the CdS or $\mathrm{ZnO}$. The dyes then emit at wavelengths for which the device exhibits a high QE. This technique has been shown to increase short circuit current up to $1.5 \mathrm{~mA} / \mathrm{cm}^{2}$ for CIGS devices ${ }^{40}$ (i.e approximately $0.9 \mathrm{~mW} / \mathrm{cm}^{2}$ for a very high-efficiency device). $1.0 \mathrm{~mA} / \mathrm{cm}^{2}$ of this current is due to enhanced blue response, and $0.5 \mathrm{~mA} / \mathrm{cm}^{2}$ due to decreased reflection of a mini-module without antireflective coating. 


\section{Conclusions}

Material properties of each layer in an NREL 20.0\%-efficient, small-area, CIGS device have been documented. Based on best proven material properties, $18 \%$-efficient, $100 \mathrm{~cm}^{2}$ devices suitable for integration into large-area modules are possible. Successful transfer of high efficiencies from small to large areas requires careful attention to minimum grid finger width, optimized cell design, high-quality transparent conductors, and AR coating. For some layers (e.g. CdS, Mo), windows of acceptable material properties for $15 \%$ devices are fairly wide. The key challenge in creating $15 \%$ large-area modules is likely maintaining long lifetimes $(>\sim 50 \mathrm{~ns})$ and high carrier densities $\left(>\sim 10^{16} \mathrm{~cm}^{-3}\right)$ in the CIGS, particularly in high-throughput processes over large areas. A better understanding of electron mobility in CIGS devices is needed to put firm limits on the required values for lifetime and carrier density. New developments related to highquality large-bandgap absorbers, non-absorbing heterojunction partners that maintain Voc, improved TCO's, and use of optics have the potential to add a few percent to module efficiency, thus relaxing requirements on the CIGS.

\section{ACKNOWLEDGMENTS}

This work was supported by the U.S. Department of Energy under Contract No. DOE-AC36-08GO28308 with the National Renewable Energy Laboratory.

\section{REFERENCES}

[1] I. Repins, M.A. Contreras, B. Egaas, C. DeHart, J. Scharf, C.L. Perkins, B. To, R. Noufi, "19.9\%-efficient $\mathrm{ZnO} / \mathrm{CdS} / \mathrm{CuInGaSe}{ }_{2}$ solar cell with 81.2\% fill factor," Progress in Photovoltaics: Research and Applications 16(3), pp. 235-239, 2008. DOI: 10.1002/pip.822

[2] M.A. Green, Solar Cells: Operating Principles, Technology, and System Applications, Prentice-Hall, 1982, pp. 153 ff.

[3] J. Kessler, J. Wennerberg, M. Bodegard, L. Stolt, "Highly efficient $\mathrm{Cu}(\mathrm{In}, \mathrm{Ga}) \mathrm{Se} 2$ mini-modules," Solar Energy Materials \& Solar Cells 75 (2003) 35-46.

[4] J.N. Duenow, "Dopants and Transport Properties of Transparent Conducting Zinc Oxide Thin Films," Doctoral thesis: Colorado School of Mines, 2008, pg 90.

[5] P. Drude, Wied. Ann. 46, 353 (1882); ibid. 48, 122 (1883); ibid. 49, 690 (1883).

[6] See, for example, K. Seeger, Semiconductor Physics: An Introduction, Springer-Verlag, 1991, pg. 348.

[7] D. Schmid, M. Ruckh, H.W. Schock, "A comprehensive characterization of the interfaces in Mo/CIS/CdS/ZnO solar cell structures", Solar Energy Materials and Solar Cells 41(2), pp.281-29.

[8] K.A. Jones, "The lattice mismatch between (112) chalcopyrite films and (0001) CdS substrates" Journal of Crystal Growth 47 (2), 1979, pp 235-244.

[9] A. Kylner, "The Role of CdS Buffer Layer in the $\mathrm{Cu}(\mathrm{In}, \mathrm{Ga}) \mathrm{Se}_{2}$ Thin Film Solar Cell," Doctoral thesis: Uppsala University, 1998.

[10] J. Kessler, M. Ruckh, D. Hariskos, U. Ruhle, R. Menner. H.W. Schock, "Interface engineering between $\mathrm{CuInSe}_{2}$ and ZnO ," Proceedings of the IEEE Photovoltaics Specialists Conference 23, 1993, pg. 447.

[11] D. Lincot, R. Ortega-Borges, J. Vedel, M. Ruckh, J. Kessler, K.O. Velthaus, D. Hariskos, H.W. Schock, "Chemical Bath Deposition of CdS on CuInSe 2 : Combining Dry and Wet Processes for High Efficiency Thin Film Solar Cells," Proceedings of the EC PVSEC 11, 1992, pg. 870. 
${ }^{[12]}$ K. Ramanathan, R.N. Bhattacharya, J. Granata, J. Webb, D. Niles, M.A. Contreras, H. Wiesner, F.S. Hasoon, R. Noufi, "Advances in the CIS Research at NREL," IEEE Photovoltaics Specialists Conference, 26, 1997, pp. 319322.

[13] K. Ramanathan, H. Wiesner, S. Asher, D. Niles, R.N. Bhattacharya, J. Keane, M.A. Contreras, R. Noufi, "High Efficiency $\mathrm{Cu}(\mathrm{In}, \mathrm{Ga}) \mathrm{Se}_{2}$ Thin Film Solar Cells Without Intermediate Buffer Layers", Proceedings of the World Conference on Photovoltaic Energy Conversion 2, 1998, pp. 477-481.

[14] T. Nakada, "Nano-structural investigations on Cd-doping into $\mathrm{Cu}(\mathrm{In}, \mathrm{Ga}) \mathrm{Se}_{2}$ thin films by chemical bath deposition process," Thin Solid Films 361-362 (21), 2000, pp. 346-352.

${ }^{15]}$ M.A. Contreras, M.J. Romero, B. To, F. Hasoon, R. Noufi, S. Ward, K. Ramanathan, "Optimization of CBD CdS process in high-efficiency $\mathrm{Cu}(\mathrm{In}, \mathrm{Ga}) \mathrm{Se}_{2}$-based solar cells", Thin Solid Films 403-404, 2002, pp. 204-211.

[16] S. Ninomiya, S. Adachi, "Optical Properties of Wurtzite CdS," Journal of Applied Physics 78(2), 1995, pp. 11831190.

[17] A.O. Pudov, "Impact of Secondary Barriers on $\mathrm{CuIn}_{1-\mathrm{x}} \mathrm{Ga}_{\mathrm{x}} \mathrm{Se}_{2}$ Solar-Cell Operation," Doctoral thesis: Colorado State University, 2005, pp. 64 ff.

[18] M. Cwil, M. Igalson, P. Zabierowski, S. Siebentritt, "Charge and doping distributions by capacitance profiling in $\mathrm{Cu}(\mathrm{In}, \mathrm{Ga}) \mathrm{Se}_{2}$ solar cells,” Journal of Applied Physics 103, 2008, DOI 063701.

[19] W.K. Metzger, I.L. Repins, M. Romero, P. Dippo, M. Contreras, R. Noufi, D. Levi, "Recombination kinetics in polycrystalline $\mathrm{Cu}(\mathrm{In}, \mathrm{Ga}) \mathrm{Se}_{2}$ solar cells," Thin Solid Films 517(7), 2009, pp. 2360-2364.

[20] W.K. Metzger, I.L. Repins, M. Contreras, "Long recombination lifetimes in high-efficiency $\mathrm{Cu}(\mathrm{In}, \mathrm{Ga}) \mathrm{Se}_{2}$ solar cells," Applied Physics Letters 93, 2008, DOI 022110.

[21] I.L. Repins, W.K. Metzger, C.L. Perkins, J.V. Li, and M.A. Contreras, "Measured Minority-Carrier Lifetime and CIGS Device Performance," IEEE Photovoltaics Specialists Conference, 34, 2009.

[22] J.W. Lee, J. D. Cohen, W.N. Shafarman, "The determination of carrier mobilities in CIGS photovoltaic devices using high-frequency admittance measurements," Thin Solid Films 480-481, 2005, pp. 336-340.

[23] E.A. Schiff, "Transport, Interfaces, and Modeling in Amorphous Silicon Based Solar Cells," Subcontract report DOE NREL/SR-520-44101, 2008, pg. v.

[24] I.L. Repins, B.J. Stanbery, D.L. Young, S.S. Li, W.K. Metzger, C. Perkins, W.N. Shafarman, M.E. Beck, L. Chen, V.K. Kapur, D. Tarrant, M.D. Gonzalez, D.G. Jensen, T.J. Anderson, X. Wang, L.L. Kerr, B. Keyes, S. Asher, A. Delahoy, B. Von Roedern, "Comparison of Device Performance and Measured Transport Parameters in WidelyVarying Cu(In,Ga)(Se,S) Solar Cells" Progress in Photovoltaics 14, 2006, pp. 25-43.

[25] M. Gloeckler, J. R. Sites, "Band-gap grading in $\mathrm{Cu}(\mathrm{In}, \mathrm{Ga}) \mathrm{Se}_{2}$ solar cells", Journal of Physics \& Chemistry of Solids 66(11), 2005, pp.1891-1894.

[26] M.A. Green, Solar Cells: Operating Principles, Technology, and System Applications, Prentice-Hall, 1982, pg. 89.

[27] M.I. Alonso, M. Garriga, C.A. Durante Rincon, E. Hernandez, M. Leon, "Optical functions of chalcopyrite $\mathrm{CuGa}_{\mathrm{x}} \mathrm{In}_{1-\mathrm{x}} \mathrm{Se}_{2}$ alloy," Applied Physics A 74, 2002, pp. $659-664$.

[28] J. Song, S.S. Li, C.H. Huang, O.D. Crisalle, T.J. Anderson, "Device modeling and simulation of the performance of $\mathrm{Cu}\left(\mathrm{In}_{1-\mathrm{x}}, \mathrm{Ga}_{\mathrm{x}}\right)$ solar cells," Solid-State Electronics 48, 2004, pp. 73-79.

[29] See, for example, S.M. Sze, Physics of Semiconductor Devices, John Wiley and Sons, 1981, pg. 92.

${ }^{[30]}$ M. Gloeckler, A.L. Fahrenbruch, J.R. Sites, "Numerical modeling of CIGS and CdTe solar cells: setting the baseline." World Conference on Photovoltaic Energy Conversion 3, 2003, pp. 491-494.

[31] C. Rincon, R. Marquez, "Defect physics of the CuInSe ${ }_{2}$ chalcopyrite semiconductor," Journal of Physics and Chemistry of Solids 60, 1999, pp. 1865-1873. 
${ }^{[32]}$ R.N. Bhattacharya, M.A. Contreras, B. Egaas, and R.N. Noufi, High efficiency thin-film $\mathrm{CuIn}_{1-\mathrm{x}} \mathrm{Ga}_{\mathrm{x}} \mathrm{Se}_{2}$ photovoltaic cells using a $\mathrm{Cd}_{1-\mathrm{x}} \mathrm{Zn}_{\mathrm{x}} \mathrm{S}$ buffer layer, Applied Physics Letters 89, 2006, 253503.

[33] R.N. Bhattacharya, J.F. Hiltner, W. Batchelor, M.A. Conteras, R.N. Noufi, and J.R. Sites, $15.4 \% \mathrm{CuIn}_{1-\mathrm{x}} \mathrm{Ga}_{\mathrm{x}} \mathrm{Se}_{2^{-}}$ based photovoltaic cells from solution-based precursor films, Thin Solid Films 361-362, 2000, pp. 396-399.

[34] P.K. Johnson, J.T. Heath, J.D. Cohen, K. Ramanathan, and J.R. Sites, A comparative study of defect states in evaporated and selenized CIGS(S) solar cells, Progress in Photovoltaics 13, 2005, pp. 579-586.

[35] B. Egaas, C. DeHart, J. Scharf, B.E. McCandless, R. Noufi , "Characterization of 19.9\%-Efficient CIGS Absorbers," IEEE Photovoltaics Specialists Conference 33, 2008.

[36] M. Gloeckler, J.R. Sites, "Potential of Submicrometer thickness $\mathrm{Cu}(\mathrm{In}, \mathrm{Ga}) \mathrm{Se}_{2}$ solar cells", Journal of Applied Physics 98, 2005, DOI 103703.

[37] M.A. Green, Solar Cells: Operating Principles, Technology, and System Applications, Prentice-Hall, 1982, pg. 146.

[38] S. Siebentritt, "Wide gap chalcopyrites: material properties and solar cells," Thin Solid Films 403-404, 2002, pp. 18.

[39] J.S. Ward, K. Ramanathan, F.S. Hasoon, T.J. Coutts, J. Keane, M.A. Contreras, T. Moriarty, R. Noufi, “A 21.5\% Efficient $\mathrm{Cu}(\mathrm{In}, \mathrm{Ga}) \mathrm{Se}_{2}$ Thin-Film Concentrator, Solar Cell," Progress in Photovoltaics 10, 2002, pp. 41-46.

[40] G.C. Glaeser, U. Rau, "Improvement of photon collection in $\mathrm{Cu}(\mathrm{In}, \mathrm{Ga}) \mathrm{Se}_{2}$ solar cells and modules by fluorescent frequency conversion," Thin Solid Films 515, 2007, pp. 5964-5967.

[41] K.R. McIntosh, G. Lau, J.N. Cotsell, K. Hanton, D.L. Batzner, F. Bettiol, B.S. Richards, "Increase in External Quantum Efficiency of Encapsulated Silicon Solar Cells from a Luminescent Down-Shifting Layer," Progress in Photovoltaics 17, 2009, pp. 191-197. 


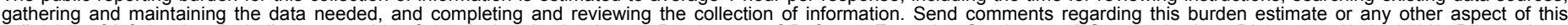

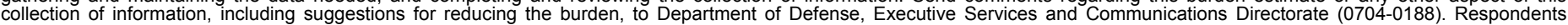

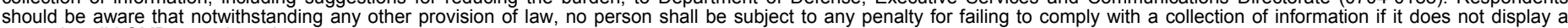

should be aware that notwithstanding

PLEASE DO NOT RETURN YOUR FORM TO THE ABOVE ORGANIZATION.

\section{REPORT DATE (DD-MM-YYYY) July 2009 \\ 2. REPORT TYPE \\ Conference Paper}

4. TITLE AND SUBTITLE

Required Materials Properties for High-Efficiency CIGS Modules: Preprint
I. Repins, S. Glynn, J. Duenow, T.J. Coutts, W. Metzger, and M.A. Contreras
3. DATES COVERED (From - To)

2-6 August 2009

5a. CONTRACT NUMBER

DE-AC36-08-GO28308

5b. GRANT NUMBER 5d. PROJECT NUMBER

NREL/CP-520-46235

5e. TASK NUMBER

PVA92330

5f. WORK UNIT NUMBER
7. PERFORMING ORGANIZATION NAME(S) AND ADDRESS(ES)

National Renewable Energy Laboratory

1617 Cole Blvd.

Golden, CO 80401-3393
8. PERFORMING ORGANIZATION

REPORT NUMBER

NREL/CP-520-46235

9. SPONSORING/MONITORING AGENCY NAME(S) AND ADDRESS(ES)

10. SPONSOR/MONITOR'S ACRONYM(S) NREL

11. SPONSORING/MONITORING AGENCY REPORT NUMBER

\section{DISTRIBUTION AVAILABILITY STATEMENT}

National Technical Information Service

U.S. Department of Commerce

5285 Port Royal Road

Springfield, VA 22161

13. SUPPLEMENTARY NOTES

\section{ABSTRACT (Maximum 200 Words)}

Relatively high proven efficiencies of CIGS devices are often cited regarding its choice as a semiconductor for photovoltaic manufacturing. Module efficiency is an important parameter, as a number of factors in the cost per watt are driven downward by increasing efficiency. Some of these factors include materials costs, throughput for a given capital investment, and installation costs. Thus, realizing high-efficiency (e.g. 15\%) large-area CIGS modules is key in both reducing cost per watt and differentiating the technology from other thin films. This paper discusses the material properties required for each layer of the CIGS device such that large-area CIGS modules can achieve efficiencies of $>15 \%$, substantially higher than the current industrial state of the art. The sensitivity of module performance to the important material parameters is quantified based on both experimental data and modeling. Necessary performance differences between small-area devices and large-area modules imposed by geometry are also quantified. Potential technical breakthroughs that may relax the requirements for each layer are discussed.

15. SUBJECT TERMS

PV; CIGS; module; material properties; high-efficiency; devices;

\begin{tabular}{|c|c|c|c|c|}
\hline \multicolumn{3}{|c|}{ 16. SECURITY CLASSIFICATION OF: } & \multirow{2}{*}{$\begin{array}{l}\text { 17. LIMITATION } \\
\text { OF ABSTRACT } \\
\text { UL }\end{array}$} & \multirow{2}{*}{$\begin{array}{ll}\text { 18. } & \text { NUMBER } \\
\text { OF PAGES }\end{array}$} \\
\hline $\begin{array}{l}\text { a. REPORT } \\
\text { Unclassified }\end{array}$ & $\begin{array}{l}\text { b. ABSTRACT } \\
\text { Unclassified }\end{array}$ & $\begin{array}{l}\text { c. THIS PAGE } \\
\text { Unclassified }\end{array}$ & & \\
\hline
\end{tabular}

19a. NAME OF RESPONSIBLE PERSON

19b. TELEPHONE NUMBER (Include area code) 